\title{
Hypoglycemic Effect Of Concomitant Administration Of Erythromycin And Tolbutamide In Alloxan-Induced Diabetes In Rats
}

\author{
Amr, A.H. Rostom*, Mohammed, H. El Bakry** and Al Sayed, A. Zaki* \\ Departments of Pharmacology, Faculties of Medicine, (Cairo* and Asuit**), \\ Al-Azhar University
}

\begin{abstract}
Erythromycin is among the antibiotics that have widespread use for treatment of community and hospital-acquired infections. Although uncommon, hypoglycemia has been reported with erythromycin and appears to occur most frequently in elderly patients with type 2 diabetes mellitus who are receiving therapy with oral hypoglycemics. The present study was designed to explore the potential effects of erythromycin on glucose metabolism in experimental animals

In the present work, alloxan was used to induce diabetes in a dose of $200 \mathrm{mg} / \mathrm{kg}$ body weight, intraperitoneally, in rats. The blood glucose level after alloxan was measured. Tolbutamide lowered blood glucose level in normal and hyperglycemic rats. Erythromycin produced lowering of blood glucose level in non diabetic rats and also, significantly potentiated the hypoglycemic action of tolbutamide in diabetic rats.
\end{abstract}

Key Words: Tolbutamide, erythromycin, alloxan, diabetes mellitus.

\section{Introduction}

Diabetes mellitus is one of the most common diseases in the world. It was estimated that 150 million patients suffer from diabetes mellitus (Zimmet, 1982). Multiple drug-drug interactions have been reported to potentiate the effect of sulfonylureas. These include anti-inflammatory agents, sulphonamides, bishydroxycoumarin, and antidepressants. Other agents such as propranolol and tetracyclines have been reported to potentiate the hypoglycemic effects of insulin (Seltzer, 1989). Erythromycin has been clinically reported to cause significant drug interactions (Periti et al., 1992). It has been reported to potentiate the effects of astemizole, carbamazepine corticosteroids, cycloserine, digoxin, ergot alkaloids, terfenadine, theophylline, triazolam, valproate and warfarin (Martell et al., 1986; Honig et al., 1992).

Alloxan exerts its diabetogenic action through producing partial or total necrosis of beta cells which is presented histopathologically by its degeneration and nuclear pykinosis (Lazarow and Palay, 1949). It is administered parenterally (intravenously, intraperitoneally or subcutaneously). The intraperitoneal or subcutanouse dose of alloxan should be 2 to 3 times higher than the intravenous one. The dose of alloxan required for inducing diabetes depends on the animal species, route of administration and nutritional status (Szkudelski, 2001). Fasted animals are more susceptible to alloxan (Szkudelski et al., 1998), whereas increased blood glucose provides partial protection (Bansal et al. 1980, Szkudelski et al., 1998).

Tolbutamide is one of the sulfonylureas, it is characterized by its short duration, it can be detected in blood after 3 minutes of its oral administration. Its peak concentration is reached within 3-5 hours and remains up to 10 hours (Goodman and Gilman, 1996).

\section{Materials And Method}

\section{Materials}

Drugs and chemical agents

1) Alloxan

Alloxan monohydrate (B.D.H., England): It is freely soluble in water. 
2) Erythromycin

Erythrocin powder (Pfizer, Egypt), contains erythromycin succinate. It is given in a dose of $50 \mathrm{mg} / \mathrm{kg}$ body weight, intramuscularly.

3) Tolbutamide

Tolbutamide powder (Hoechst, Egypt), was administered orally in a dose of $100 \mathrm{mg} / \mathrm{kg}$ body weight, twice daily.

\section{Animals}

Male albino rats weighing 130-150 gm were used in this study. Animal food (pellets) and water were freely supplied. Animals were divided into 5 groups, each of 8 rats.

Group 1: Served as control to study blood glucose level of control non-treated rats and after giving alloxan.

Group 2: Served to study the effect of tolbutamide on blood glucose level in alloxanized diabetic rats.

Group 3: Served to study the effect of erythromycin on blood glucose level in control non-treated rats.

Group 4: Served to study the effect of erythromycin on blood glucose level of alloxanized diabetic rats.

Group 5: Served to study the effect of erythromycin with tolbutamide on blood glucose level of alloxanized diabetic rats.

\section{Procedures and Method;}

1. Induction of diabetes:

Diabetes was induced by intraperitoneal administration of alloxan monohydrate, in a dose of $200 \mathrm{mg} / \mathrm{kg}$ body weight in a dose volume of $2 \mathrm{ml}$. (Gomeriand and Goldner, 1943; Mcleod, 1970; Szkudelski, 2001). The intraperitoneal route of alloxan was chosen as it has a wider safety margin than the intravenous route.

2. Collection of blood samples and determination of blood glucose level:

Blood samples were taken after 5 hours fasting (Mirsky et al., 1956) from the tail veins of rats. Samples were collected 10 days after diabetes induction procedure. Blood glucose level was determined using a portable glucose analyzer (Eliziane et al., 2003).

\section{Statistics:}

Results were presented as arithmetic means \pm standard error $\left(\mathrm{M}_{ \pm} \mathrm{SE}\right)$. Statistical significance was calculated by one tailed Student's "t" test. $\mathrm{P}<0.05$ was considered significant.

\section{Results}

Effect of alloxan on blood glucose of control non-treated rats:

The blood glucose level of control non-treated rats was $83.75 \pm 6.9 \mathrm{mg} / 100 \mathrm{ml}$ blood when measured 5 hours after fasting. Intraperitoneal alloxan administration in a dose of $200 \mathrm{mg} / \mathrm{kg}$ body weight induced significant increase in the blood glucose level. Measurements were done on the 3 rd, 10 th and 17th days post alloxan administration. The blood glucose levels were $(616.25 \pm \quad 37.7), \quad(516.25 \pm 31.6)$ and $(436.25 \pm 38.7) \mathrm{mg} / \mathrm{dl}$, respectively (Table 1 and Figure 1). The increased blood sugar level was significant with all measurements $(\mathrm{P}<0.05)$ as compared with normal rats. This relative decline of the hyperglycemic state recorded on the 17th day is most probably due to regeneration of some of the beta-cells of the pancreas.

Effect of erythromycin on blood glucose of rats:

The effect of different doses of erythromycin on the blood glucose level of normal rats was studied. The results showed that, erythromycin when given daily for 7 successive days in the following doses: 25, $50,100 \mathrm{mg} / \mathrm{kg}$ body weight, induced a significant decrease in blood glucose level from $83.75 \pm 6.9 \mathrm{mg} / \mathrm{dl}$ to $66.25 \pm 4.8,58.75$ \pm 5.9 and $54.37 \pm 5.2 \mathrm{mg} / \mathrm{dl}$, respectively. $\mathrm{P}$ value was $<0.05$ in all the dose levels of erythromycin used (Table 3 and Figure 3). Erythromycin administration, in a dose of $50 \mathrm{mg} / \mathrm{kg}$ body weight, to alloxan diabetic rats starting from the $10^{\text {th }}$ day post-alloxan and for 7 successive days, produced nonsignificant change in the hyperglycemic state. The blood glucose level was $(423.75 \pm 55.6) \mathrm{mg} / \mathrm{dl}$, while the control blood glucose level was $(436.25 \pm 38.7)$ $\mathrm{mg} / \mathrm{dl}(\mathrm{p}>0.05)$ (Table 4). However, the 
combined therapy of tolbutamide (100 $\mathrm{mg} / \mathrm{kg}$ ) and erythromycin $(50 \mathrm{mg} / \mathrm{kg})$ for 7 successive days starting from the $10^{\text {th }}$ day post alloxan produced a significant lowering of the blood glucose level from $423.75 \pm 55.6 \mathrm{mg} / \mathrm{dl}$ to $125.62 \pm 20.4 \mathrm{mg} / \mathrm{dl}$ $(\mathrm{P}<0.05)$ (Table 4 and Figure 4).

Effect of tolbutamide on blood glucose of normal non-treated and alloxan diabetic rats:

Tolbutamide was given in dose of 100 $\mathrm{mg} / \mathrm{kg}$ body weight twice daily for 7 successive days to normal and to alloxanized rats starting from the $10^{\text {th }}$ day post-alloxan injection. The results showed significant decrease in the blood glucose level of control rats from $(83 \pm 3.6) \mathrm{mg} / \mathrm{dl}$ to $(58.75 \pm 4.8) \mathrm{mg} / \mathrm{dl},(\mathrm{P}<0.05)$ (Table 2). Also, the alloxanized rats showed significant decrease in the blood glucose level from $516.25+31.6 \mathrm{mg} / \mathrm{dl}$ to $285.5 \pm 22.7 \mathrm{mg} / \mathrm{dl}(\mathrm{P}<0.05)$ (Table 2 and Figure 2). These results suggest the regeneration of the beta cells of Langerhans as well as its insulin functioning capacity.

Table1: Blood glucose level $(\mathrm{mg} / \mathrm{dl})$ in control rats and 3, 10 and 17 days after alloxan (200mg/kg b.w., i.p.).

\begin{tabular}{|c|c|c|c|c|}
\hline (Rat numbers) & $\begin{array}{c}\text { Blood glucose } \\
\text { Control (zero } \\
\text { time) }\end{array}$ & $\begin{array}{c}\text { Blood glucose } \\
3^{\text {rd }} \text { day }\end{array}$ & $\begin{array}{c}\text { Blood glucose } \\
10^{\text {th }} \text { day }\end{array}$ & $\begin{array}{c}\text { Blood glucose } \\
17^{\text {th }} \text { day }\end{array}$ \\
\hline 1 & 70 & 680 & 480 & 410 \\
2 & 85 & 560 & 500 & 500 \\
3 & 85 & 630 & 560 & 380 \\
4 & 95 & 580 & 480 & 400 \\
5 & 80 & 550 & 540 & 480 \\
6 & 80 & 640 & 490 & 420 \\
7 & 85 & 600 & 560 & 460 \\
8 & 90 & $616.25 \pm 37.7$ & $516.25 \pm 31.6$ & $436.25 \pm 38.7$ \\
\hline Mean \pm S.E. & $83.75 \pm 6.9$ & $<0.01$ & $<0.01$ & $<0.01$ \\
\hline P value** & \multicolumn{3}{|r}{} \\
\hline
\end{tabular}

* Blood glucose was measured 5 hours after meals.

** $\mathrm{P}$ value calculated in comparison with control.

Figure 1: Blood glucose level $(\mathrm{mg} / \mathrm{dl})$ in control rats and 3,10 and 17 days after alloxan (200mg/kg b.w., i.p.).

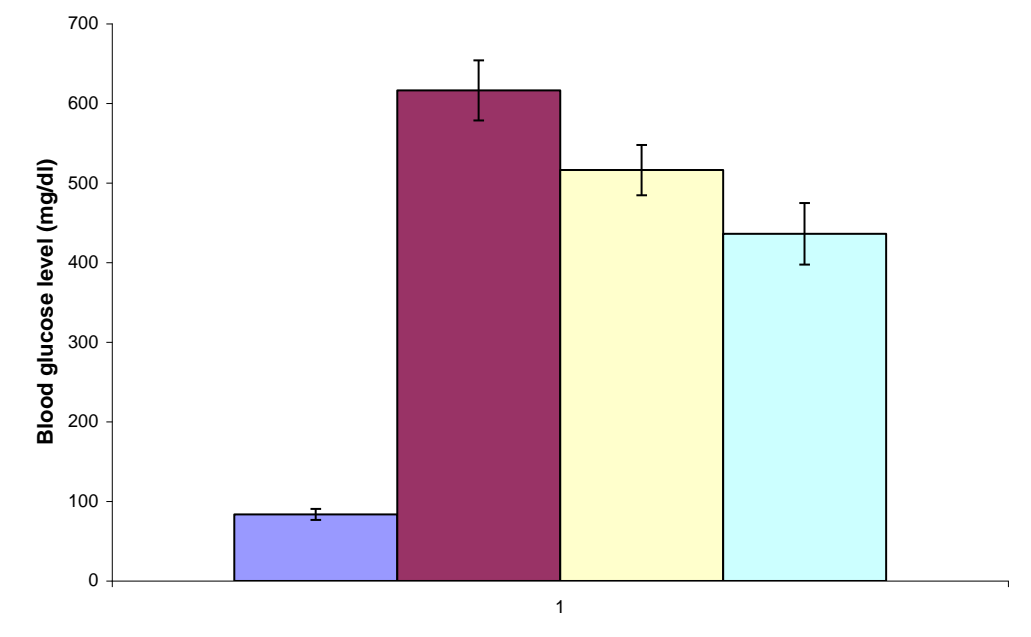

$\begin{array}{ll}\square \text { control } & \square \text { blood glucose level after } 3 \text { days } \\ \square \text { blood glucose level after } 10 \text { days } & \square \text { blood glucose level after } 17 \text { days }\end{array}$


Table 2: Effect of tolbutamide (tolb., $100 \mathrm{mg} / \mathrm{kg} \mathrm{b.w.,} \mathrm{twice} \mathrm{daily} \mathrm{orally} \mathrm{for} 7$ successive days) on blood glucose level $(\mathrm{mg} / \mathrm{dl})$ of normal non-treated and on alloxan diabetic rats 10 days after induction of diabetes

\begin{tabular}{|c|c|c|c|c|}
\hline (Rat numbers) & Control & $\begin{array}{c}\text { Tolb. Treated non- } \\
\text { alloxan treated }\end{array}$ & $\begin{array}{c}\text { Alloxan treated } \\
\text { non-tolb. Treated }\end{array}$ & $\begin{array}{c}\text { Alloxan and tolb. } \\
\text { Treated }\end{array}$ \\
\hline 1 & 70 & 50 & 480 & 260 \\
2 & 85 & 55 & 500 & 290 \\
3 & 85 & 60 & 560 & 300 \\
4 & 95 & 65 & 480 & 320 \\
5 & 80 & 55 & 540 & 300 \\
6 & 80 & 65 & 490 & 280 \\
7 & 85 & 60 & 560 & 260 \\
8 & 90 & 60 & 520 & 250 \\
\hline Mean \pm S.E. & $83.75 \pm 6.9$ & $58.75 \pm 4.8$ & $516.25 \pm 31.6$ & $285.5 \pm 22.7$ \\
\hline P value & $\mathrm{P}$ & $<0.05$ & $<0.05$ & $<0.05$ \\
\hline
\end{tabular}

Blood glucose was measured 5 hours after meal

$\mathrm{P}$ value calculated in comparison with control.

Figure 2:Effect of tolbutamide (tolb., $100 \mathrm{mg} / \mathrm{kg} \mathrm{b.w.,} \mathrm{twice} \mathrm{daily} \mathrm{orally} \mathrm{for} 7$ successive days) on blood glucose level ( $\mathrm{mg} / \mathrm{dl}$ ) of normal non-treated and on alloxan diabetic rats $\mathbf{1 0}$ days after induction of diabetes

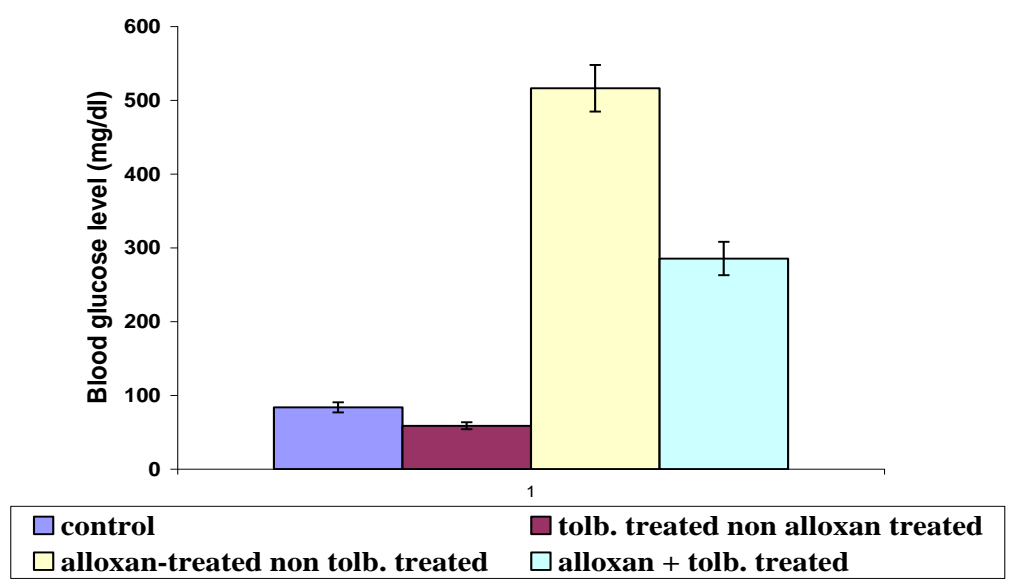

Table3: Effect of different doses of erythromycin (eryt.) for 7 successive days on blood glucose level $(\mathrm{mg} / \mathrm{dl})$ of normal non-alloxan treated rats

\begin{tabular}{|c|c|c|c|c|}
\hline (Rat numbers) & Control & $\begin{array}{c}\text { Erythromycin } \\
25 \mathrm{mg} / \mathrm{kg}\end{array}$ & $\begin{array}{c}\text { Erythromycin } \\
50 \mathrm{mg} / \mathrm{kg}\end{array}$ & $\begin{array}{c}\text { Erythromycin } \\
100 \mathrm{mg} / \mathrm{kg}\end{array}$ \\
\hline 1 & 70 & 70 & 60 & 65 \\
2 & 85 & 65 & 65 & 50 \\
3 & 85 & 70 & 65 & 55 \\
4 & 95 & 60 & 50 & 50 \\
5 & 80 & 65 & 55 & 50 \\
6 & 80 & 75 & 50 & 55 \\
7 & 85 & 65 & 65 & 60 \\
8 & 90 & 60 & 60 & 50 \\
\hline Mean \pm S.E. & $83.75 \pm 6.9$ & $66.25 \pm 4.8$ & $58.75 \pm 5.9$ & $54.37 \pm 5.2$ \\
\hline P value & & $<0.05$ & $<0.05$ & $<0.05$ \\
\hline
\end{tabular}

Blood glucose level was measured 5 hours after meals

$\mathrm{P}$ value calculated in comparison with control. 
Figure 3:Effect of different doses of erythromycin (eryt.) for 7 successive days on blood glucose level (mg/dl) of normal nonalloxan treated rats

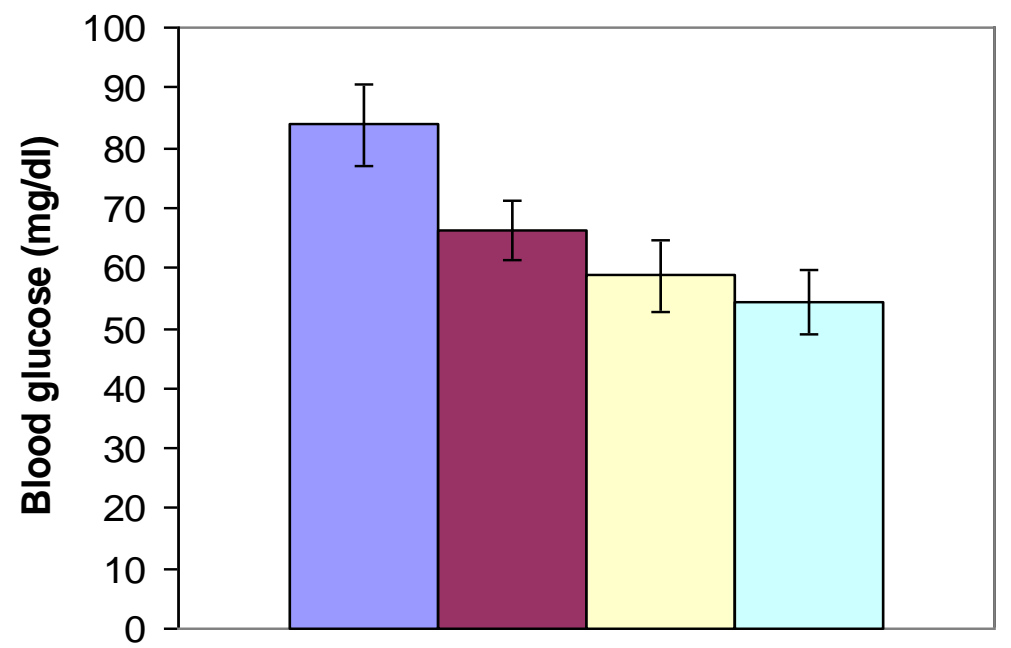

$\square$ control $\square 25 \mathrm{mg}$ eryt. $\square 50 \mathrm{mg}$ eryt. $\square 100 \mathrm{mg}$ eryt.

Table 4: Effect of erythromycin $(50 \mathrm{mg} / \mathrm{kg}$ b.w.) for 7 successive days on blood glucose level $(\mathrm{mg} / \mathrm{dl})$ of alloxan diabetic rats $(10$ days $)$ and diabetic rats treated by tolbutamide (tolb., $100 \mathrm{mg} / \mathrm{kg}$ b.w. twice daily orally for 7 successive days).

\begin{tabular}{|l|l|l|l|}
\hline (Rat numbers) & Alloxan & Erythromycin + alloxan & $\begin{array}{l}\text { Erythromycin + alloxan } \\
+ \text { tolb. }\end{array}$ \\
\hline 1 & 410 & 500 & 120 \\
2 & 500 & 360 & 145 \\
3 & 380 & 420 & 130 \\
4 & 400 & 320 & 100 \\
5 & 480 & 450 & 110 \\
6 & 420 & 420 & 165 \\
7 & 460 & 440 & 105 \\
8 & 440 & 480 & 130 \\
\hline Mean \pm S.E. & $436.25+38.7$ & $423.75 \pm 55.6$ & $125.62 \pm 20.4$ \\
\hline P value & & $>0.05$ & $<0.01$ \\
\hline
\end{tabular}

Blood glucose was measured 5 hours after meals.

$\mathrm{P}$ value calculated in comparison with control. 
Figure 4: Effect of erythromycin (50 mg / kg b.w., for 7 successive days) on blood glucose level (mg/dl) of alloxan diabetic rats (10 days) and diabetic rats treated by tolbutamide (tolb., $100 \mathrm{mg} / \mathrm{kg} \mathrm{b.w.} \mathrm{twice} \mathrm{daily,} \mathrm{orally} \mathrm{for} 7$ successive days).

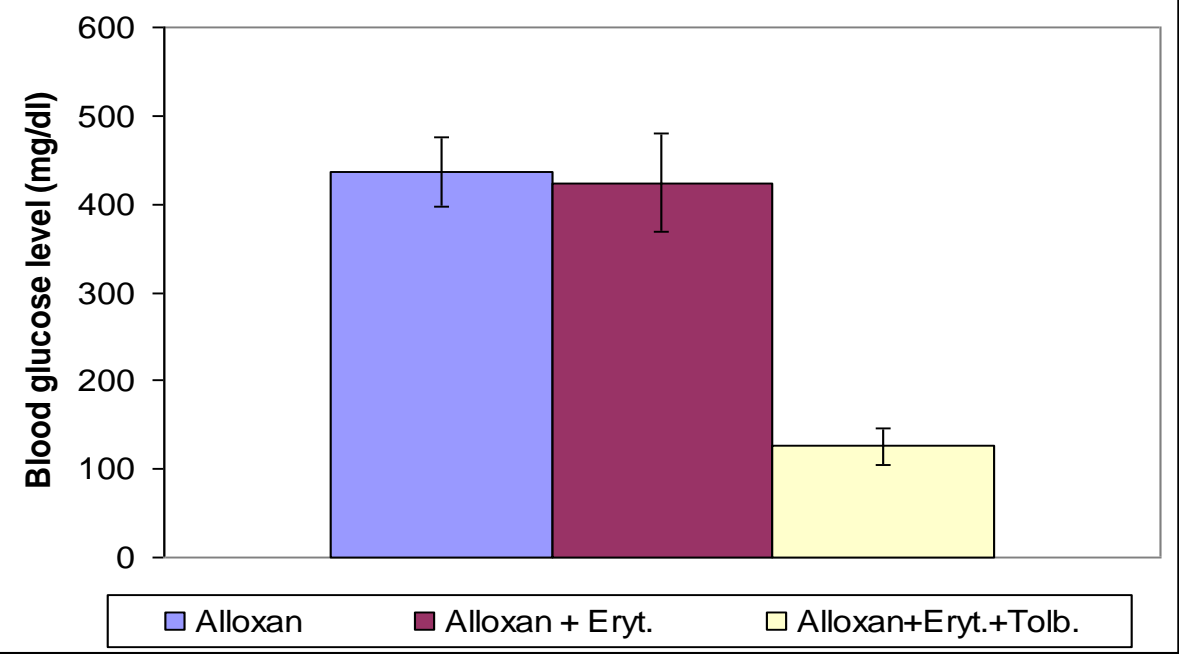

\section{Discussion}

Diabetes mellitus is considered to be one of the most widely spread metabolic diseases known all over the world.

The combined use of oral hypoglycemics and antibiotics is very common, as some diabetics are subjected to infection and are in need for antibiotics administration (Davidson, 1981).

In the present study, diabetes was induced by alloxan, which is a pancreotoxic substance given intraperitoneally to rats in a dose of $200 \mathrm{mg} / \mathrm{kg}$ body weight, as rats are considered good models for diabetes mellitus (Smith, 1946).

The blood glucose level of control rats used in this work was $83+3.6 \mathrm{mg} / \mathrm{dL}$. The intraperitoneal administration of alloxan caused significant hyperglycemia (Table 1). The blood glucose level in alloxanized rats was estimated on the $3^{\text {rd }}, 10^{\text {th }}$ and $17^{\text {th }}$ day post-alloxan injection, and was $620 \pm 19.8$, $520 \pm 18.76$ and $440 \pm 20.39 \mathrm{mg} / \mathrm{dl}$, respectively. There were significant changes between the three levels and that of the control $(\mathrm{P}<0.05)$. The action of alloxan on the pancreas is preceded by its rapid uptake by the B cells (Boquist et al., 1983). Rapid uptake by insulin-secreting cells has been proposed to be one of the important features determining alloxan diabetogenicity. Another aspect concerns the formation of reactive oxygen. A similar uptake of alloxan also takes place in the liver. However, the liver and other tissues are more resistant to reactive oxygen species in comparison to pancreatic B cells and this resistance protects these tissues against alloxan toxicity (Tiedge et al, 1997; Szkudelski, 2001).

The relative decline of the diabetic state on the $10^{\text {th }}$ day and on the $17^{\text {th }}$ day $(520 \pm 18.76$ and $440 \pm 20.39 \mathrm{mg} / \mathrm{dl}$, respectively) might be attributed to the beta-cells that survived the alloxan toxic effect or due to new formation of betacells from the duct epithelium of the exocrine portion of the pancreas. These findings coincided with Manhaff and De Loach (1948), Abdel Wahed et al., (1964) and Bunnag et al. (1967) who reported the recovery of the diabetic state after alloxan. However, the present results did not coincide with the findings of Tomlison and Yusof (1983) that the diabetes induced by alloxan is a permanent irreversible process.

Tolbutamide administration in a dose of $100 \mathrm{mg} / \mathrm{kg}$ orally, twice daily for 7 successive days from the $10^{\text {th }}$ day postalloxan injection, induced a significant decrease in the hyperglycemic state from $440 \pm 20.39 \mathrm{mg} / \mathrm{dl}$ to $339 \pm 45.17 \mathrm{mg} / \mathrm{dl}$ 
$(\mathrm{P}<0.05)$. This effect of tolbutamide might be attributed to regeneration of functioning beta-cells that secrete insulin in amounts which might be just sufficient to decrease the blood glucose but not to bring it back to normal. This relative improvement of the diabetic state was verified by Halt et al. (1955). However, the results in the present work differed from that of Mirsky et al. (1956) who found that tolbutamide was ineffective in treating alloxan-diabetic rats.

Erythromycin, the oldest member of the macrolide group of antibiotics, has been widely used since 1952 in the management of infections. It has been considered as the drug of choice for Legionnaire's disease, pertussis, diphtheria, lower respiratory tract infections caused by Mycopneumoniae, Chlamydia pneumoniae and Chlamydia trachomatis, and enteritis causes by Campylobacter jejuni. It is also indicated for the treatment of syphilis, for streptococcal, staphylococcal and pneumococcal infections, genital infections caused by Ureaplasma urealyticum, and to prevent rheumatic fever and endocarditis in patients, who are allergic to beta lactam antibiotics (Henry, 2000).

A number of salt derivatives of erythromycin were introduced in an attempt to improve its tolerability, pharmacokinetics and dosage schedule. Although, these preparations were successful in improving its tolerability, no derivative was successful in reducing its drug interactions (Mastour et al., 2002).

Several mechanisms exist by which erythromycin interacts with other drugs or vice versa. The most common mechanism involves the inhibition of various subclasses of the cytochrome P450 enzyme system. Erythromycin is metabolized by CYP3A and CYP1A and initially it causes an induction of these enzymes. However, this is rapidly followed by significant inhibition through the formation of inactive enzyme/metabolite complexes (Guy and Amsden, 1995)

The administration of erythromycin in three different dose levels 25, 50 and 100 $\mathrm{mg} / \mathrm{kg}$ body weight for 7 successive days to normal rats produced significant decrease
$(\mathrm{P}<0.05)$ in the blood glucose levels. This hypoglycemic effect of erythromycin might be due to its inhibitory action on the mitochondrial protein synthesis and thus would preserve insulin from being destroyed by the liver glutathione insulin transhydrogenase; this explanation is in accordance with the opinion of Wheelden and Lehninger (1966) and Varandani and Nafz (1976).

Since there was no significant difference between blood glucose levels of rats treated by different doses of erythromycin, the $(50 \mathrm{mg} / \mathrm{kg}$ dose $)$ was chosen for further experiments i.e. in combination with tolbutamide.

The administration of erythromycin $(50 \mathrm{mg} / \mathrm{kg}$ ) for 7 successive days starting from the $10^{\text {th }}$ day post-alloxan injection produced a non-significant effect in the blood glucose level (Table 4) compared to the control alloxan diabetic rats. These results might be due to inhibition on peripheral glucose utilization or due to damage of liver cells by alloxan intoxication (Luken et al., 1949).

The administration of erythromycin, which inhibits the activity of liver microsomal enzymes (Christensen and Shovested, 1969), and in combination with tolbutamide which is metabolized in the liver after alloxan injection produced a marked decrease in the blood glucose level which was $105 \pm 11.31 \mathrm{mg} / \mathrm{dl}$ compared to that of the control alloxanized rats treated by tolbutamide alone (was $339 \pm 45.17 \mathrm{mg} / \mathrm{dl})$. That was explained by Thomas and Ikeda (1966) that erythromycin caused an increase in the half-life time of tolbutamide (normally 510 hours) and accumulation of unchanged tolbutamide in the plasma with more beta cell stimulation and insulin production.

In conclusion, the results showed that erythromycin administration to normal rats produced a significant decrease in the blood glucose level, while its administration to alloxan diabetic rats produced a non-significant change in the blood glucose level. However, erythromycin greatly and significantly potentiated the hypoglycemic effect of tolbutamide when given in combination. 


\section{References}

1- Abdel Wahed, H., Chaleb, M.A. and Hegazy, M. R. (1964): J. Pharm. Pharmcol., 16, 422- 426.

2- Al-Ghamdi, M.S. and Suman Jain (2002): Pakistan J. Med. Res.Vol.41 No.(4):57-58.

3- Bansal, R., Ahmad N. and Kidwai, J.R. (1980): Acta Diabetol. Lat. 17: 135-143.

4- Basaria, S., Braga, M. and Moore, W.T. (2002): South Med. J. Nov, 95(11):1353-4.

5- Boquist, L., Nelson, L. and Lorentzon, $R$. (1983): Endocrinology, 113: 943-948.

6- Bussing, R. and Gende A. (2002): Diabetes Care 25:1659-1661.

7- Bunnag, S.C., Waner, N. E. and Bung, S. (1967): Diabetes, 16: 83-89.

8- Christensen, L. K. and Shovested, L. (1969): Lancet, 27: 1397-1399.

9- Covington, D.S., Xue, H., Pizzini, R., Lally, K., Andrassy, R.J. (1993): Diabetic Res., 23: 47-53.

10- Davidson, M.E. (1981): A Wiley Medical Application -John Willey and Sons N.Y., p.: $3-11$.

11- Eliziane Nitz de Carvalho, Nestor Antônio Schmidt de Carvalho et Ferreira LM. (2003): Acta Cir. Bras. vol.18 no. spe São Paulo.

12- Goodman, L.S. and Gilman, A. (1996): The Pharmacological Basis of Therapeutics, $9^{\text {th }}$. Edition, McGraw Publishing Co., P.: 1507-1513.

13- Gruppuso, P.A., Boylan, J.M., Posner, B.I., Faure, R., Brautigan, L. (1990): J. Clin. Invest. 85: 1754-1760.

14- Guy, W. and Amsden, A. (1995): Ann. Pharmacother,29: 906-917.

15- Gomeriand, G. and Goldner, M.G. (1943): Proc. Soc. Exp. Biol. and Med., 54: $287-290$.

16- Grandmohol, M. (1970): Chemical Laboratory Methods and Diagnosis, Vol. (1) $7^{\text {th }}$ edition, $p . \therefore 77-90$.

17- Halt , C.U., Holt, L.V., Kroner, B. and Kuhanu,J.(1955): Arch. Exp. Path. Bertin. 224:66. Cauted from mirskry, et. al. (1954), Proc.Soc., Exp.Biol. and Med.91,473- 477.

18- Henry, F. (2000): Chambers in antimicrobial agents: protein synthesis inhibitors and miscellaneous agents. In: Goodman and Gilman's the Pharmacological Basis of Therapeutics. $10^{\text {th }}$ edition. New York: McGraw Hill, 1250-6.

19- Honig, P. K., Woosley, R.L., Zamani, K., Conner, D. P., and Cantellina, L. R.
(1992): Clin., Pharmacol., Ther., 52: 23138.

20- Lazarow, A. and Palay, S.L. (1946): J. Lab. Clin. Med., 31, $1104-1105$.

21- Lazarow, A. and Palay, S.L. (1949): Physiol. Rev., 28:48-52.

22- Luken , F.D.W., Kennedy, W.B. and Charles, J. (1949): Proc . Soc . Exp. Biol. and Med., 70: $113-116$.

23- Manhaff, L.J. and De Loach W. (1948): Proc. Soc Exp. Biol. and Med. 68:120.

24- Martell, R., Heinrichs, D., Stiller, C.R., Jenner, M., Keown, P. A., and Martell, R. (1986): Ann. Intern. Med.,104: 660661.

25- Mastour, S., Al-Ghamdi and Suman Jain (2002): Pakistan J. Med. Res., Vol. 41 No.(4): 57- 58.

26- Mcleod, L. J. (1970): Pharmacological Experiments on intact preparations $1^{\text {st }}$ edition, E .\& E . Livingstone, p.: 9-11.

27- Mirsky, I.A., Gladys, P. and Robert, J. (1956): Proc . Soc . Exp. Biol. and Med., 91, 475- 477.

28- Pad Makar, K. and Lazarow, A. (1969): Diabetes, 18: 589-97.

29- Periti, P., Mazzei, T., Mini, E., and Novelli, A (1992): Clin. Pharmacokinet., 23:106-131.

30- Petrakis I., Chalkiadakis G., Vrachassotakis N., Sciacca V., Vassilakis S., Xynos E. (1999): Digestive Diseases, 17:241-247

31- Seltzer, H.S. (1989): Endocrinol Metab. Clin. North Am., 18:163-183.

32- Smith , G.M. (1946): Lancet, 2: 215- 217.

33- Stone, S.H. (1954): Science , 119: 100102.

34- Stakly, I. (1967): Drug Interaction and their Metabolism, $1^{\text {st }}$ edition, Blackwell Scientific Publication, p.: $6-7$.

35- Szkudelski T., Kandulska, K. and Okulicz, M. (1998): Physiol. Res., 47: 343346.

36- Szkudelski, T. (2001): Physiosl. Res., 50: 536-546.

37- Tiedge, M., Lortz S., Drinkgern J. and Lenzen S., (1997): Diabetes, 46: 17331742.

38- Thomas, R.C. and Ikeda , G.J. (1966): J. Med . Chem., 9: 507-509.

39- Tomlson, D. R. and Yusef, A.P. (1983): J. Auton. Pharmac. , 3:257-263.

40- Varandani , P.T. and Nafz, M.A. (1976): Biochem. Biophys. Acta, 1: 732-739.

41- Wheelden, L.W. and Lehninger, A.L. (1966): Biochemistry, 5 : 3533-3545.

42- Zimmet, P. (1982): Diabetologia, 22: 399 $-411$. 


\section{أثر استعمال الأريثروسين الى جاتب تولبيوتاميد على مستوى سكر الام في الفئران المصابة بارتفاع سكر الدم الدم

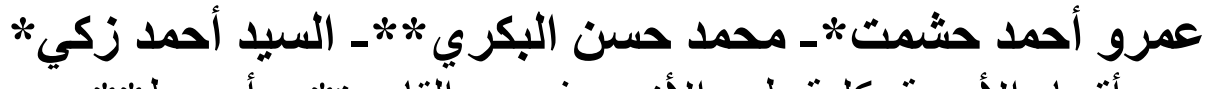

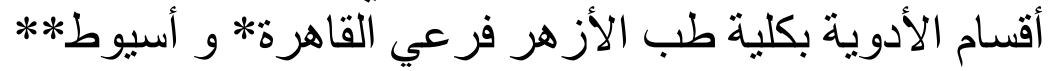

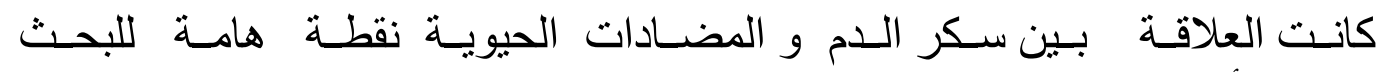

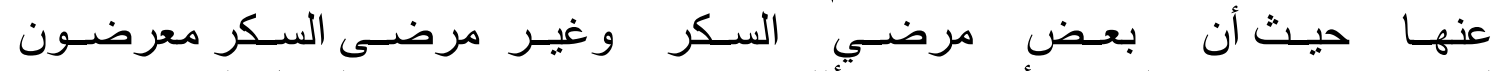

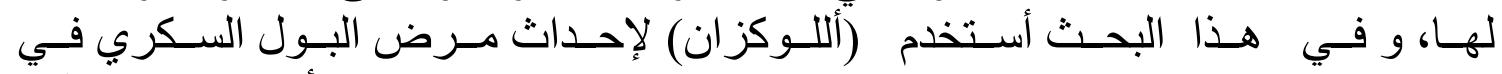

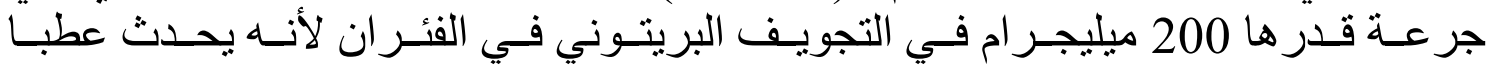

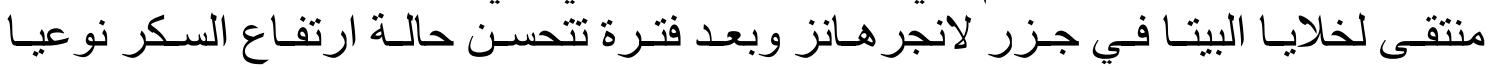
نتيجة تجديد بناء خلايا آلبيتا النشطة.

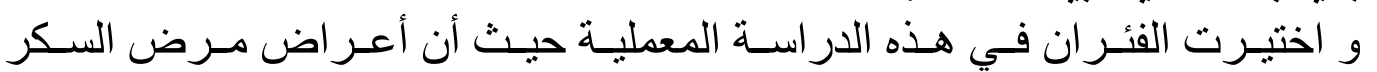
المحدثة بمادة الالوكز ان تشابه مثيلتها في الأنسان.

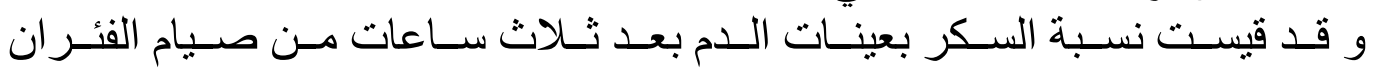

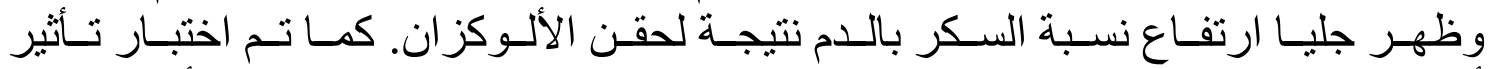

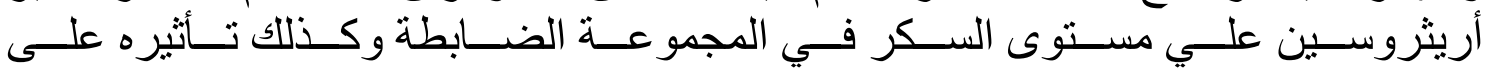

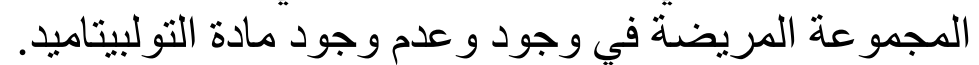

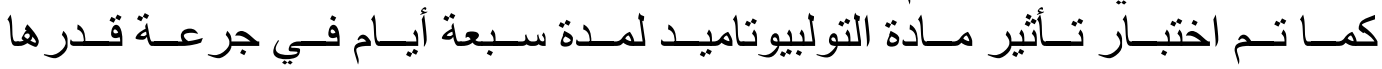

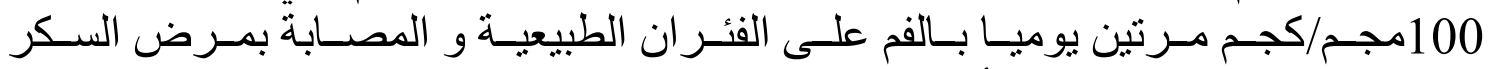

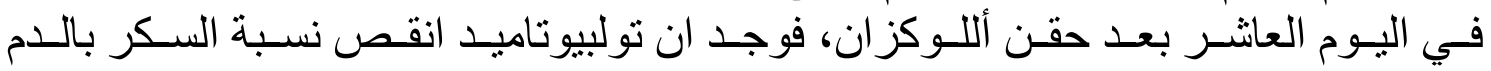

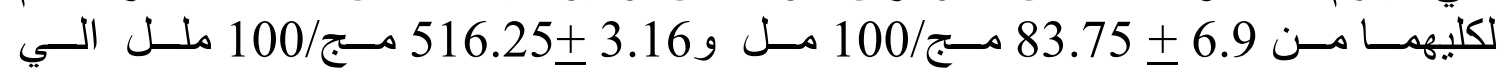

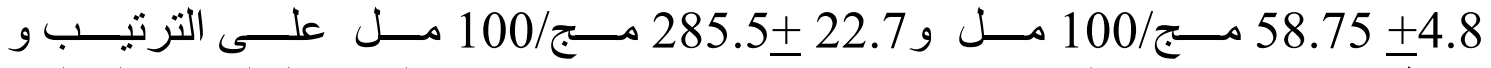

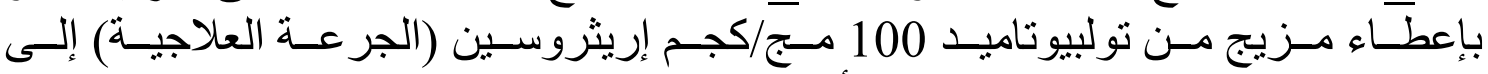

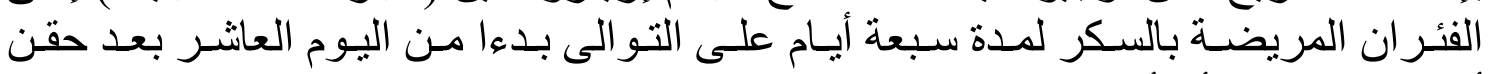

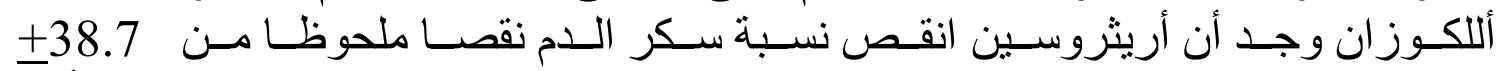

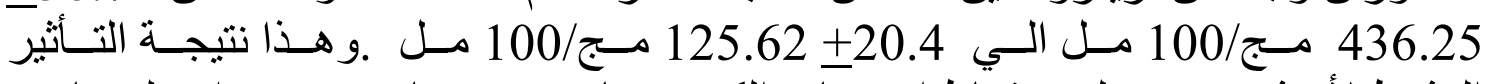

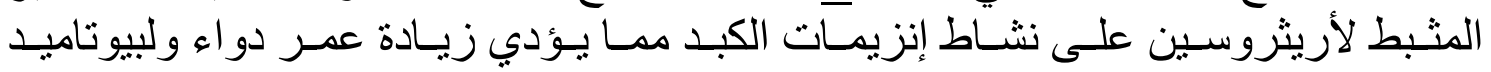
في الدم وبالتالي زيادة نشاطه. 